\title{
Relationship between Body Condition and some Reproductive Parameters of Holstein Cattle
}

\author{
Myrtill Gráff, Ágnes Süli, Szabina Szilágyi, Edit Mikó* \\ University of Szeged Faculty of Agriculture, 6800 Hódmezővásárhely, Andrássy street 15., Hungary
}

\begin{abstract}
The body condition scoring system (BCS) is a means of accurately determining body condition of dairy cows, independent of body weight and farm size. The body condition scores represent a subjective visual or tactile (or both) evaluation of the amount of subcutaneous fat in a cow. The system is a useful method of evaluating body energy reserves and is used widely for evaluating nutritional status in dairy cows. The different stages of lactation have different recommended scores. BCS change during the lactation period depends on the milk production, reproduction and health status. Extreme body condition loss in the early lactation can cause irregular heats, longer time to first ovulation, and fail to conceive. The aim of this research was to determine the effect of BCS on Holstein cows' reproduction. The relationship between some BCS parameters: BCS at calving $\left(B C S_{c}\right)$, minimum $B C S$ after calving $\left(B C S_{\min }\right)$ and the reduction of BCS after calving $\left(B C S_{r}\right)$ on one hand and three reproductive parameters: the days from calving to first service (DFS), number of inseminations to conception (NIC), and days open (DO) on the other hand were studied in three private dairy farms in South Hungary. BCS were determined monthly during milk recording. A total of 786 records of Holstein cows from 1 to 3 lactation were evaluated. DFS was significantly $(P<5 \%)$ influenced by $\mathrm{BCS}_{\mathrm{s}}$ and $\mathrm{BCS}_{\min }$. The number of inseminations to conception (NIC) varied according to the individual cow. In the present studywas between 1 and 12. The most favourable DO values were observed in the group having $>3.5 \mathrm{BCSC}$ (150.04 days), the group with 3.0-3.5 $\mathrm{BCS}_{\min }(138.92)$ and the group having $>1 \mathrm{BCS}$. There was no significant relationship found between DO and the BCS groups.
\end{abstract}

Keywords: BCS, reproduction, days from calving to first service (DFS), number of inseminations to conception (NIC), days open (DO)

\section{Introduction}

The reproduction of dairy cattle is a very complex trait. There is negative relationship between the increasing milk production and reproduction [1, 2, 3 , 4]. At the beginning of lactation, the milk production has a definite priority over the reproduction [5]. The declining fertility results have been verified during recent decades. Butler [1] reported in his study that in the U.S.A. the proportion of pregnant cows after the first insemination was $65 \%$ in 1951 while it was only $40 \%$ in 1996 . In the UK [6] changes of this very

\section{* Corresponding author: Edit Miko, mikone@mgk.u-szeged.hu}

(cc) BY-NC-ND $\odot 2017$ Myrtill Gráff et al., published by De Gruyter Open. This work was licensed under the Creative Commons Attribution-NonCommercialNoDerivs 3.0 License same parameter were analysed between 19751982 and 1995-1998, and it was found that the pregnancy rate to first service declined from $55.6 \%$ to $39.7 \%$. The antagonism between the improving milk production and deteriorating reproduction may be partially explained by the changes in the genetic bases. The cumulative incidence of reproductive and other disorders as consequences of insufficient nutrition (especially lack of energy) due to the increased milk production is more important. The declining fertility is probably a combination of a variety of physiological and management factors that have an additive effect [7]. The management, feeding, milk production and genetics are the main reasons of the declining reproduction parameters in modern dairy cattle $[8,3]$. The negative energy balance is a prominent risk factor for the low 
fertility [9]. The extent and duration of the energy deficiency period after calving are associated with the low fertility after [10]. According to Szenci et al. [11] the sooner the cows restore their energy balance, the sooner they will start cycling. The energy deficit is well controllable by the change of the condition. Body condition change from 50 to 80 days after calving significantly affects the reproduction parameters. One unit or more loss of BCS (on a five-point scale) extends the dates of the first ovulation, the first recorded oestrus, and the first insemination. The proportion of pregnancy at first service is smaller and the NIC is higher in these cows. Lucy et al. [12] showed that body condition loss in the dry period is related to the higher proportion of reproduction disorders. Gillund et al. [13] did not showe a correlation between reproduction and BCS at calving; however, they claimed that the BCS change is a good indicator of fertility results. The primiparous cows calving with a BCS $<3$ have a late resumption of ovarian activity [14]. Samarütel et al. [9] also analysed the relationship between the $\mathrm{BCS}$ at calving and the reproduction. In their work they analysed the BCS of thin (BCS<3.0), medium $(B C S=3.25-3.5)$ and fat $(B C S>3.75)$ cows. The best results have been observed in the group of medium BCS. None of the fat cows became pregnant in the first insemination. In contrast, the first service conception rates were $17 \%$ and $23 \%$ for the groups with low and medium BCS, respectively. The interval from parturition to first insemination was the longest in case of the cows with low BCS. The loss of BCS in early lactation is unfavourably related to reproductive performance, particularly in high genetic merit animals than the change in BCS from week 1 to week 10 [4, 15]. The level of BCS change after calving greatly affects the luteal activity in high-producing dairy cows. The loss of body condition between calving and first service should be restricted to below 0.5 BCS unit to avoid a detrimental effect on reproductive performance [16].

The aim of this research was to determine the effect of BCS on Holstein cows' reproduction.

\section{Material and Methods}

The study was conducted in three private dairy farms in South Hungary. A total of 786 records of BCS from Holstein cows being in 1 to 3 lactation were evaluated. The data of measurements was recorded by dairy farm management software (RISKA).

During the analysis of reproductive performance we introduced three reproductive parameters: the number of days from calving to first service (DFS), the days open (DO) which is the calving-to- conception interval, and the number of inseminations to conception (NIC).

We examined the connection between the reproductive parameters and the BCS in different parities.

When making the groups according to the BSC at calving $\left(\mathrm{BCS}_{\mathrm{C}}\right)$ we made 5 groups $\left(\mathrm{BCS}_{\mathrm{c}}=2.0\right.$; $\mathrm{BCS}_{\mathrm{c}}=2.5 ; . \quad \mathrm{BCS}_{\mathrm{c}}=3.0 ; \mathrm{BCS}_{\mathrm{c}}=3.5$ and $\mathrm{BCS}_{\mathrm{c}}$ $>3.5$ ).

Minimum BCS $\left(\mathrm{BCS}_{\min }\right)$ was defined as the lowest $\mathrm{BCS}$ obtained after calving. There were three groups of minimum BCS (BCS ${ }_{\min }=1.5-2$, $\left.B C S_{\min }=2.5, \quad B C S_{\min }=2.0-3.5\right)$. Finally, we examined the reduction of BSC after calving. There were four groups formed $\left(B C S_{r}=0.0 ; B C S_{r}\right.$ $\left.=-0.5, \mathrm{BCS}_{\mathrm{r}}=-1, \mathrm{BCS}_{\mathrm{r}}>-1\right)$.

Cows were monthly recorded by BCS using a 5grade scoring system, which describes 1 point is emaciated and 5 points refer to an obese cow. To achieve more sensitivity, 0.50 points subunits were also used. BCS was determined during the milk recording scheme by the same person using a scale according to Edmonson et al [17].

The data were tested by analysis of variance (One-Way ANOVA). The means were compared by Duncan's multiple range test based on the 0.05 level of probability and all statistical analyses were performed using SPSS 18.0 for Windows.

\section{Results and Discussions}

The numbers of recordings for $\mathrm{BCS}_{\mathrm{c}}$ were 372 . The median of $B C S_{c}$ was 3.0 (ranging from 2.0 to 5.0). The results are presented in the Table 1.

The number of the days from calving to first service (DFS) was not significantly different among the groups $(P>5 \%)$. These results are similar with those of Nicolini et al. [18] who reported that no effect of body condition at calving was observed on commencement of luteal activity. By contrast, in the study of O'Hara et al. [19] BCS at calving had a nonlinear relation with fertility in progesterone profiles, indicating that it had a negative effect on the fertility of both thin and over-conditioned cows. This period (Table 1) was the shortest in case of cows with 3.5 BCS $_{c}$ (99 days) and the longest in case of cows with 2.0 $\mathrm{BCS}_{\mathrm{c}}$ (167 days). When comparing the groups, the biggest difference (75 days) was found between the group pair 2.0-3.5, but this difference was not significant $(P>5 \%)$.

Out of the groups made according to the $\mathrm{BCS}_{\mathrm{c}}$ the cows with $3.5 \mathrm{BCS}_{\mathrm{c}}$ got pregnant within the shortest time (days open), however, no significant difference was confirmed among the groups $(P>5 \%$, Table 1). The extremes were represented by the cows with $>3.5$ and $2 \mathrm{BCS}_{\mathrm{c}}$ (150 and 229 days, respectively). 
The number of inseminations to conception (NIC) varied according to the individual cow. In the present study it was between 1 and 12. The $40.9 \%$ of the cows got pregnant at the first insemination. When examining the body condition at calving, the NIC extremes had an average between 2.18 and 2.44. We can claim that the $\mathrm{NIC}$ of the studied stock was quite favourable, but the maximum values of almost all groups were extremely high (9 and 12).

Reproduction parameters with regard to the $\mathrm{BCS}_{\mathrm{c}}$

Table 1

\begin{tabular}{c|c|c|c|c|c|c}
\hline $\mathrm{BCS}_{\mathrm{c}}$ & $\mathrm{n}$ & $\begin{array}{c}\text { DFS } \\
(\mathrm{mean}+\mathrm{SD})\end{array}$ & $\begin{array}{c}\mathrm{DO} \\
(\mathrm{mean}+\mathrm{SD})\end{array}$ & $\begin{array}{c}\mathrm{NIC} \\
(\mathrm{mean} \pm \mathrm{SD})\end{array}$ & $\begin{array}{c}\mathrm{NIC} \\
\min \end{array}$ & $\begin{array}{c}\mathrm{NIC} \\
\mathrm{max}\end{array}$ \\
\hline 2.0 & 4 & $167.25 \pm 67.99^{\mathrm{a}}$ & $229.00 \pm 111.82$ & $2.25 \pm 0.50$ & 2 & 3 \\
2.5 & 82 & $112.85 \pm 42.94^{\mathrm{b}}$ & $159.88 \pm 78.53$ & $2.18 \pm 1.52$ & 1 & 9 \\
3.0 & 205 & $106.75 \pm 39.3^{\mathrm{b}}$ & $161.19 \pm 80.38$ & $2.40 \pm 1.86$ & 1 & 12 \\
3.5 & 54 & $99.44 \pm 37.73^{\mathrm{b}}$ & $154.06 \pm 88.04$ & $2.44 \pm 1.85$ & 1 & 9 \\
$>3.5$ & 27 & $101.85 \pm 37.19^{\mathrm{a}}$ & $150.04 \pm 64.16$ & $2.33 \pm 1.86$ & 1 & 9 \\
\hline
\end{tabular}

${ }^{a . b}$ Means in the same column with no common superscripts differ $(\mathrm{P}<5 \%)$.

When grouping the cows based on the minimum BCS (Table 2) after calving $\left(\mathrm{BCS}_{\min }\right)$, the largest rate was observed in the $2.5 \mathrm{BCS}_{\min }$ group (56\%) while the lowest proportion was observed in the 3.0-3.5 $\mathrm{BCS}_{\min }(7 \%)$. In Ruegg and Milton [20] work the proportion of $\mathrm{BCS}_{\min }<2.5$ was $73 \%$ while the rates of $\mathrm{BCS}_{\min }>3.0$ was $11.5 \%$.

In terms of reproduction it can be observed that days from calving to first service (DFS) were most favourable in case of the animals with a $\mathrm{BCS}_{\min }$ not lower than 3.0. In this group, it can also be observed that DFS falls into the ideal 70-90-day interval [21]. Between the group pairs the statistical analysis confirmed a significant difference $(P<5 \%)$ between the group of 1.5-2.0
$\mathrm{BCS}_{\min }$ cows on one hand and the other two groups on the other hand.

When examining the DO the variance analysis showed non-significant differences $(P>5 \%)$. The shortest days open occurred in cows with the 3.03.5 BCS $_{\min }$. There was a 33-day difference between the average open days of the $\mathrm{BCS}_{\min }$ of 1.5-2.0 and 3-3.5.

In case of the NIC, we got opposite results to that of the number of days until the first insemination. Here the lowest value appeared in the group of cows with 3.0-3.5 $\mathrm{BCS}_{\min }$. The extreme values of NIC varied between 1 to 9 , the higher value was observed in the $2.5 \mathrm{BCS}_{\min }$ group.

Reproduction parameters with regard to the $\mathrm{BCS}_{\min }$

Table 2

\begin{tabular}{c|c|c|c|c|c|c}
\hline $\mathrm{BCS}_{\min }$ & $\mathrm{n}$ & $\begin{array}{c}\mathrm{DFS} \\
(\text { mean+SD) }\end{array}$ & $\begin{array}{c}\text { DO } \\
(\text { mean+SD) }\end{array}$ & $\begin{array}{c}\text { NIC } \\
(\text { mean+SD) }\end{array}$ & $\begin{array}{c}\text { NIC } \\
\min \end{array}$ & $\begin{array}{c}\text { NIC } \\
\max \end{array}$ \\
\hline $1.5-2.0$ & 137 & $115.42 \pm 45.78^{\mathrm{a}}$ & $168.77 \pm 81.32$ & $2.29 \pm 1.62$ & 1 & 9 \\
2.5 & 210 & $104.13 \pm 37.34^{\mathrm{b}}$ & $156.76 \pm 81.59$ & $2.41 \pm 1.93$ & 1 & 12 \\
$3.0-3.5$ & 25 & $89.84 \pm 25.53^{\mathrm{b}}$ & $135.92 \pm 57.41$ & $2.24 \pm 1.23$ & 1 & 5 \\
\hline
\end{tabular}

\footnotetext{
${ }^{a . b}$ Means in the same column with no common superscripts differ $(\mathrm{P}<05)$.
}

Finally, we examined the effect of the difference between the $\mathrm{BCS}_{\mathrm{c}}$ and the $\mathrm{BCS}_{\min }$. The values are shown in Table 3. According to Gillund et al. [9] the BCS change is a good indicator of fertility results. This statement is true in our study, too. In an earlier work Balakrishnan et al. [22] found that body condition loss during first month of calving caused longer DFS. When analysing the BCS changes it can be observed (Table 3) that conception occurred at latest (longer DFS) in the cows with a BCS loss of 1 point (165.57 days). This result confirms the negative correlation between milk yield and reproduction, while being in energy deficiency period the animal will not conceive. No significant difference was found $(P>5 \%)$, however, between the groups with deteriorating BCS after calving. Ruegg and Milton [20] also did not find significant differences between the loss of BCS, DFS and DO.

When looking at the NIC we found that there is no considerable difference between the groups. The difference between the extreme averages was only 0.26 , therefore the condition change after calving obviously did not have any effect on the NIC.

However, Szenci [11] showed that the cows with one unit or more loss of BCS (on a five-point scale) had higher NIC figures. 
Table 3.

Reproduction parameters with regard to the reduction $\mathrm{BCS}_{\mathrm{r}}$

\begin{tabular}{c|c|c|c|c|c|c}
\hline $\mathbf{B C S}_{\mathbf{r}}$ & $\mathbf{n}$ & $\begin{array}{c}\text { DFS } \\
\text { (mean+Sd) }\end{array}$ & $\begin{array}{c}\text { DO } \\
\text { (mean+Sd) }\end{array}$ & $\begin{array}{c}\mathbf{N I C} \\
\text { (mean+Sd) }\end{array}$ & $\begin{array}{c}\mathbf{N I C} \\
\mathbf{m i n}\end{array}$ & $\begin{array}{c}\text { NIC } \\
\mathbf{m a x}\end{array}$ \\
\hline 0 & 11 & $140.64 \pm 54.89$ & $110.36 \pm 52.67$ & $2.09 \pm 0.70$ & 1 & 3 \\
0.5 & 252 & $159.37 \pm 80.85$ & $106.56 \pm 39.68$ & $2.35 \pm 1.79$ & 1 & 12 \\
1 & 77 & $165.57 \pm 84.47$ & $109.84 \pm 40.33$ & $2.42 \pm 1.84$ & 1 & 9 \\
$>1$ & 32 & $155.69 \pm 75.46$ & $106.28 \pm 45.22$ & $2.31 \pm 1.80$ & 1 & 9 \\
\hline
\end{tabular}

\section{Conclusions}

In our study, we examined different reproduction parameters (days from calving to first service (DFS), number of inseminations to conception (NIC), days open (DO)) in relation to BCS at calving $\left(\mathrm{BCS}_{\mathrm{C}}\right)$, minimum $\mathrm{BCS}$ after calving $\left(B C S_{\min }\right)$, and reduction of BCS after calving $\left(B C S_{r}\right)$. The aim of this research was to determine the effect of BCS on Holstein cows' reproduction. The DFS was significantly $(P<5 \%)$ influenced by $B C S_{C}$ and $B S_{\text {min }}$. The number of inseminations to conception (NIC) varied according to the individual cow. In the present study it was between 1 and 12. The most favourable DO values were observed in the group of $>3.5 \mathrm{BCS}_{\mathrm{c}}$ (150.04 days), the group of $3.0-3.5 \mathrm{BCS}_{\min }$ (138.92) and the group of $>1$ BCS $_{\mathrm{r}}$. There were no significant relationship between $\mathrm{DO}$ and the formed BCS groups. However, when summarizing the results, this type of BCS grouping was not suitable enough for detection of the relationship between body condition and reproduction of dairy cattle.

Additional investigation of the role of BCS in reproduction is needed.

\section{References}

1. Butler, W. R. (2005). Inhibition of ovulation in the postpartum cow and the lactating sow. Livestock Production Science, 98, 1-2, 5-12. https://doi.org/10.1016/j.livprodsci.2005.10.007

2. Gutierrez, C. G., Gong, J. G., Bramley, T. A. \& Webb, R. (2006). Selection on predicted breeding value for milk production delays ovulation independently of changes in follicular development, milk production and body weight. Animal Reproduction Science, 95, 3-4, 193-205.

http://dx.doi.org/10.1016/j.anireprosci.2005.09.015

3. Huszenicza, Gy., Kulcsár, M., Dankó, G., Balogh, O. \& Gaál, T. (2003). A nagy tejtermelésü tehén takarmányozásának, tejtermelésének és szaporodóképességének kapcsolata. Irodalmi áttekintés 4. A ketonanyag-képződés fokozódása és annak klinikai következményei. Magyar Állatorvosok Lapja, 125, 203-208

4. Pryce, J. E., Royal, M. D., Garnsworthy, P. C. \& Mao, I. L. (2004). Fertility in the high-producing dairy cow. Livestock Production Science, 86, 1-3, 125-135. https://doi.org/10.1016/S0301-6226(03)00145-3
5. Ferguson, J. D. (2001). Nutrition and reproduction in dairy herds. Intermountain Nutr. Conf., Salt Lake City, UT. Utah State Univ., Logan., pp 65-82

6. Royal, M. D., Pryce, J. E., Woolliams, J. A. \& Flint, A. P. F. (2002). The genetic relationship between commencement of luteal activity and calving interval, body condition score, production, and linear type traits in holstein-friesian dairy cattle. Journal of Dairy Science, $\quad 85, \quad 11, \quad 3071-3080$. https://doi.org/10.3168/jds.S0022-0302(02)74394-4

7. Lucy, M. C. (2001). Reproductive loss in highproducing dairy cattle: where will it end? Journal of Dairy Science, $84(6), \quad 1277-$ $1293 . \quad$ http://dx.doi.org/10.3168/jds.S00220302(01)70158-0

8. Chagas, L. M., Bass, J. J., Blache, D., Burke, C. R., Kay, J. K., Lindsay, D. R., Lucy, M. C., Martin, G. B., Meier, S., Rhodes, F. M., Roche, J. R., Thatcher, W. W. \& Webb, R. (2007). Invited review: New perspectives on the roles of nutrition and metabolic priorities in the subfertility of high-producing dairy cows. Journal of Dairy Science, 90(9), 4022-4032. https://doi.org/10.3168/jds.2006-852

9. Samarütel, J., Ling, K., Waldmann, A., Jaakson, H., Kaart, T. \& Leesmae, A. (2008). Field trial on progesterone cycles, metabolic profiles, body condition score and their relation to fertility in Estonian Holstein dairy cows. Reproduction in Domestic Animals, 43(4), 457-463. $\quad$ https://doi.org/10.1111/j.14390531.2007.00935.x

10. Butler, W. R. (1998). Review: Effect of Protein nutrition on ovarian and uterine physiology in dairy cattle. Journal of Dairy Science, 81(9), 2533$2539 . \quad$ http://dx.doi.org/10.3168/jds.S00220302(98)70146-8

11. Szenci, O. (1999). Az ellés utáni időszak szaporodásbiológiai gondozása tejhasznú tehenészetekben. Magyar Állatorvosok Lapja, 121, 7881.

12. Hoedemaker, M., Prange, D. \& Gundelach, Y. (2009). Body Condition Change Ante- and Postpartum, Health and Reproductive Performance in German Holstein Cows. Reproduction in domestic animals, 44(2), 167-173. https://doi.org/10.1111/j.14390531.2007.00992.x.

13. Gillund, P., Reksen, O., Gröhn, Y. T. \& Karlberg, K. (2001). Body condition related to ketosis and reproductive performance in Norwegian dairy cows. Journal of Dairy Science, 84(6), 1390$1396 . \quad$ http://dx.doi.org/10.3168/jds.S00220302(01)70170-1

14. Meikle, A., Kulcsar, M., Chilliard, Y., Febel, H., Delavaud, C., Cavestany, D. \& Chilibroste, P. (2004). 
Effects of parity and body condition at parturition on endocrine and reproductive parameters of the cow. Reproduction, 127(6), 727-737.

15. Tamadon, A., Kafi, M., Saeb, M., Mirzaei, A. \& Saeb, S. (2011). Relationships between insulin-like growth factor-I, milk yield, body condition score, and postpartum luteal activity in high-producing dairy cows. Tropical Animal Health and Production, 43(1), 29-34. https://doi.org/10.1007/s11250-010-9650-y.

16. Buckley, F.- O'sullivan, K., Mee, J. F., Evans, R. D., Dillon, P. (2003). Relationships among milk yield, body condition, cow weight, and reproduction in springcalved holstein-friesians. Journal of Dairy Science, 86(7), 2308-2319. http://dx.doi.org/10.3168/jds.S00220302(03)73823-5

17. Edmonson, AJ., Lean LJ., Weaver LD., Farver T. \& Webster G. (1989). A body condition scoring chart for Holstein dairy cows. Journal of Dairy Science, 72, 68-78. https://doi.org/10.3168/jds.S00220302(89)79081-0

18. Nicolini, P., Carriquiry, M. \& Meikle, A. (2013). A polymorphism in the insulin-like growth factor 1 gene is associated with postpartum resumption of ovarian cyclicity in Holstein-Friesian cows under grazing conditions. Acta Veterinaria Scandinavica, 55(1):11. doi:10.1186/1751-0147-55-11. 10.1186/1751-0147-5511

19. O'Hara, LA., Båge, R., Holtenius, K. (2015). Impaired insulin sensitivity and reduced fertility in obese dairy cows. Acta Veterinaria Scandinavica, 57(Suppl 1):O11. doi: 10.1186/1751-0147-57-S1-O11

20. Ruegg, P.L. \& Milton, R.L. (1995). Body condition score of Holstein cows on Prince Edward Island, Canada: Relationship with yield, reproductive performance and disease. Journal of Dairy Science, 78(3), 552-64. http://dx.doi.org/10.3168/jds.S00220302(95)76666-8

21. Báder, E., Gergácz, Z., Györkös, I. \& Báder, P. (2004). Az első termékenyítés idejének alakulása magas holstein-fríz vérhányadú tejelő állományokban. Holstein magazin, 12(3), 27-29.

22. Balakrishnan, M., Ramesha K. P. \& Chinnalya G. P. (1997). Effect of post-partum body condition loss on performance in crossbred cows - an assessment through body condition scoring. Indian Journal of Dairy Sci., 50, 393-397. 